\title{
Pengaruh Low Organized Games terhadap Derajat Kebugaran Jasmani Siswa Sekolah Dasar
}

\author{
Rizky Aulia Hidayat $^{{ }^{*} \text {, Dian Budiana }}{ }^{1}$,Andi Suntoda Situmorang ${ }^{1}$ \\ ${ }^{1}$ Prodi Pendidikan Jasmani Sekolah Dasar, Uiversitas Pendidikan Indonesia, Indonesia
}

\section{Info Artikel}

Sejarah Artikel:

Diterima Februari 2020

Disetujui April 2020

Dipublikasikan Mei 2020

\section{Keywords:}

Kebugaran Jasmani, Low Organized Games.

\begin{abstract}
Abstrak
Studi ini dilatarbelakangi pembelajaran low organized games sebagai penunjang dalam meningkatkan kebugaran jasmani. Studi ini bertujuan untuk mengembangkan program pembelajaran low organized games dalam pendidikan jasmani untuk meningkatkan kebugaran jasmani siswa. Metode yang digunakan dalam studi ini yaitu eksperimen dengan desain pretest posttest control group design. Populasi dalam studi ini yaitu siswa kelas V. Sampel dalam studi ini sebanyak 62 siswa. Studi ini dilakukan sebanyak 12 kali pertemuan. Analisis data yang dilakukan yaitu dengan bantuan software SPSS versi 22.00 for Windows. Hasil studi menunjukkan terdapat pengaruh yang signifikan dari penerapan pembelajaran low organized games terhadap derajat kebugaran jasmani siswa, terdapat pengaruh yang signifikan dari penerapan pembelajaran kelompok kontrol terhadap derajat kebugaran jasmani siswa, dan pembelajaran low organized games lebih berpengaruh dari pembelajaran kelompok kontrol terhadap derajat kebugaran jasmani siswa.
\end{abstract}

\begin{abstract}
This study is motivated by learning low organized games as a support in improving physical fitness. This study aims to develop a low organized games learning program in physical education to improve students physical fitness. The method used in this study is an experiment with a pretest posttest control group design. The population in this study were fifth grade students. The sample in this study was 62 students This study was conducted as many as 12 meetings. Data processing using SPSS software version 22.00 for Windows. The results showed that there was a significant effect of the implementation of learning low organized games on the degree of physical fitness students, there was a significant effect of the application of control group learning on the physical fitness degree of students, and learning of low organized games was more influential compared to control group learning on physical fitness degrees of students.
\end{abstract}




\section{PENDAHULUAN}

Pendidikan jasmani merupakan bagian dari pendidikan nasional yang bertujuan untuk mengembangkan kebugaran jasmani, mental, emosional, sosial, serta pola hidup sehat dengan aktivitas jasmani. Pendidikan jasmani merupakan suatu proses pendidikan yang memanfaatkan aktivitas fisik yang dilakukan secara sadar dan sistematik melalui berbagai kegiatan dalam rangka memperoleh kemampuan dan keterampilan jasmani, pertumbuhan, kecerdasan, emosional, dan pembentukan watak (Juliantine, 2015).

Peranan pendidikan jasmani sangat penting dalam ranah pendidikan, pendidikan jasmani senantiasa memberikan kesempatan kepada siswa untuk terlibat langsung dalam aneka pengalaman belajar melalui aktivitas jasmani, bermain dan aktivitas olahraga secara sistematis. Melalui pembelajaran penjas siswa akan memperoleh pengalaman yang erat kaitannya dengan kesan pribadi yang menyenangkan, berbagai ungkapan kreatif, inovatif, keterampilan gerak, kesegaran jasmani, pola hidup sehat, pengetahuan dan pemahaman terhadap gerak manusia juga akan dapat membentuk kepribadian yang positif.

Pada pelaksanaan pembelajaran pendidikan jasmani di sekolah guru cenderung memberikan materi yang kurang menarik dengan strategi pembelajaran yang monoton, sehingga siswa kurang antusias mengikuti pembelajaran pendidikan jasmani. Tingkat kebugaran jasmani yang dimiliki siswa juga masih tergolong rendah, siswa seringkali mengeluh pada saat melakukan pembelajaran pendidikan jasmani dengan alasan panas, lelah dan sebagainya.

Pada pelaksanaan pembelajaran di sekolah, guru hendaknya memilih program pembelajaran yang menarik, seperti menerapkan pembelajaran pendidikan jasmani berbasis permainan untuk dapat menarik perhatian serta minat belajar siswa, agar sesuai dengan karakteristik siswa sekolah dasar yang senang bergerak, senang bekerja dalam kelompok dan cenderung masih suka bermain. Permainan akan membuat siswa senang dalam melakukan pembelajaran pendidikan jasmani. Oleh karena itu guru harus kreatif dalam membuat program pembelajaran pendidikan jasmani seperti menerapkan modifikasi-modifikasi permainan, karena dengan aktivitas permainan siswa tidak hanya bersenang-senang tetapi juga belajar.

Bermain bagi siswa merupakan kebutuhan hidup seperti halnya kebutuhan akan makan, minum, tidur, dan lain-lain. Bermain merupakan suatu bentuk kegiatan yang sangat disenangi oleh anak. Karena rasa senang inilah akan terbentuk suatu situasi yang dapat digunakan sebagai wahana untuk mencapai tujuan pendidikan. Dengan bermain, akan timbul suatu situasi yang memungkinkan terlaksananya proses pendidikan. Dengan adanya rasa senang menyebabkan anak berbuat secara sepontan, sehingga keaadan asli anak akan mudah dilihat.

Low Organized Games merupakan program pembelajaran pendidikan jasmani berbasis aktivitas permainan sederhana yang dirancang berpedoman pada kurikulum pendidikan jasmani di sekolah dasar. Apabila merujuk pada Permendikbud RI Nomor 21 Tahun 2016, maka low organized games bertujuan untuk menyediakan proses pembelajaran secara interaktif, inspiratif, menyenangkan, dan memotivasi siswa untuk berpartisipasi aktif melalui aktivitas permainan dalam pembelajaran penjas sesuai dengan kompetensi dasar 4.3 mempraktikkan kombinasi gerak dasar jalan, lari, lompat, dan lempar melalui permainan/olahraga yang dimodifikasi dan atau olahraga tradisional

Low organized games diidentifikasi sebagai permainan kelompok yang aktif dan terorganisir serta pengalaman gerakan yang memelihara pembelajaran sosial, emosional, kognitif, fisik, mendorong pengembangan kepercayaan, inisiatif, dan ikatan untuk semua individu. Low organized games merupakan permainan yang berada di luar wilayah permainan formal yang umumnya sudah berkembang karena terdapat peraturan baku serta organisasi yang mengelolanya, seperti permainan sepak bola, basket, voli, dsb (Mahendra, 2007). Artinya, low organized games adalah aktivitas jasmani yang di dalamnya mengandung unsur-unsur yang menyenangkan, karena sudah dilengkapi 
dengan adanya unsur yang mengandung kompetisi sederhana, mengandung fantasi atau imajinasi (seperti memainkan peran binatang atau sebuah benda), atau mengandung unsur adaptasi dan modifikasi peraturan.

Low organized games stimulate various types of perceptual motor development such as body awareness, body image, body and space relationships, motor planning, movement duplication, and two-part body coordination (White, 2004). Artinya, permainan sederhana merangsang berbagai jenis perkembangan motorik persepsi seperti kesadaran tubuh, citra tubuh, hubungan tubuh dan ruang, perencanaan motorik, duplikasi gerakan, dan koordinasi dua bagian tubuh.

Low organized games bermanfaat bagi pengembangan ranah psikomotor, kognitif, dan afektif bagi peserta didik. Pada ranah psikomotor bersifat pengembangan kualitas fisik dan pengembangan keterampilan manipulatif sebagai komponen penting dari keterampilan dasar. Pada ranah kognitif permainan sederhana bermanfaat bagi pengembangan kemampuan berpikir dan melatih peserta didik dalam mengambil keputusan kritis. Pada ranah afektif, permainan ini bermanfaat untuk membina rasa percaya diri peserta didik, kemampuan bekerjasama, atau mengembangkan kekompakan dan sifat-sifat kejujuran (Mahendra, 2007).

Program pembelajaran low organized
games memiliki manfaat untuk
mengembangkan kebugaran jasmani. Manfaat
low organized games yaitu untuk mengembangkan kebugaran jasmani yang bisa meningkat jika aktivitas fisik digunakan dengan cardio-respiratory, kekuatan, ketahanan, dan fleksibilitas (White, 2004). Tujuan low organized games adalah untuk memaksimalkan permainan dan partisipasi semua pemain, untuk menciptakan lingkungan yang mendorong permainan yang adil dan menekankan pentingnya kebugaran, kerjasama, dan kesenangan sembari mengembangkan setidaknya satu keterampilan permainan dan keterampilan manajemen tubuh. Dengan demikian dapat disimpulkan bahwa low organized games mempunyai sasaran yang jelas manfaatnya, dan berguna bagi siswa sebagai penunjang dalam menjalani kehidupannya, meningkatkan kebugaran jasmani, dan rasa sosialnya sesuai dengan kompetensi dasar 4.5 mempraktikkan aktivitas latihan daya tahan jantung (cardio respiratory) untuk pengembangan kebugaran jasmani.

Kebugaran jasmani merupakan derajat sehat seseorang yang menjadi dasar dalam segala aktivitasnya dan seseorang tersebut tidak mengalami kelelahan yang berarti. Kebugaran jasmani adalah kemampuan jasmani yang dapat menyesuaikan fungsi alat-alat tubuhnya terhadap tugas jasmani tertentu atau terhadap keadaan lingkungan yang harus diatasi dengan cara yang efisien, tanpa kelelahan yang berlebihan dan telah pulih sempurna sebelum datang tugas yang sama pada esok harinya (Giriwijoyo, 2012). Kebugaran jasmani sangat penting bagi keberlangsungan dan penunjang hidup manusia, aktivitas-aktivitas jasmani selalu dipergunakan dalam kehidupan seharihari selama kehidupan manusia itu berlangsung. Karena jika tubuh tidak ditunjang dengan kesehatan yang optimal maka tidak akan bekerja dan berfungsi sebagaimana mestinya.

Kebugaran jasmani sangat penting bagi kehidupan manusia. Dengan adanya kebugaran jasmani dari dalam diri seseorang maka akan membuat orang tersebut bisa melakukan segala aktivitas yang dia kehendaki, seperti bekerja, bermain, berolahraga dan lain sebagainya. Memelihara dan meningkatkan kebugaran jasmani akan bermanfaat bagi kemampuan fungsi organ tubuh, seperti lebih mampu dan lebih tahan dalam gerak atau bekerja, tidak mudah lelah, cepat pulih dari kesehatan, berkurangnya resiko terserang penyakit non infeksi, seperti penyakit jantung dan pembuluh darah (Giriwijoyo, 2010).

Faktor-faktor yang mempengaruhi kebugaran jasmani terbagi menjadi lima bagian, diantaranya sebagai berikut:

1) Umur; kebugaran jasmani anak-anak meningkat sampai mencapai maksimal pada usia 25-30 tahun, kemudian akan terjadi penurunan kapasitas fungsional dari seluruh organ tubuh, kira-kira sebesar $0,8-1 \%$ pertahun, tetapi bila rajin berolahraga penurunan ini dapat dikurangi sampai separuhnya. 
2) Jenis kelamin; sampai pubertas biasanya kebugaran jasmani anak lakilaki hampir sama dengan anak perempuan, tetapi setelah pubertas anak laki-laki biasanya memiliki nilai yang jauh lebih besar.

3) Genetik; berpengaruh terhadap kepasitas jantung paru, postur tubuh, obesitas, haemoglobin/sel darah, dan serat otot.

4) Makanan; daya tahan yang tinggi bila mengkonsumsi tinggi karbohidrat (60-70\%). Diet tinggi protein terutama untuk memperbesar otot dan untuk olahraga yang memerlukan kekuatan otot yang besar.

5) Rokok; kadar $\mathrm{CO}$ yang dihisap akan mengurangi nilai VO2 maks, yang berpengaruh terhadap daya tahan, selain itu menurut penelitian Perkins dan Sexton, nicotine yang ada, dapat memperbesar pengeluaran energi dan mengurangi nafsu makan (Wiarto, 2015).

Hal demikian menjelaskan betapa pentingnya kebugaran jasmani bagi manusia. Tidak kalah penting juga untuk anak-anak sekolah dasar, anak-anak yang sedang dalam masa pertumbuhan dan perkembangan yang sehari-harinya selalu diisi bermain, mereka membutuhkan kebugaran jasmani yang bagus sebagai penunjang untuk kehidupan di masa kini dan masa depannya. Karena kebutuhan akan kebugaran jasmani yang baik akan selalu di butuhkan dalam jangka yang panjang agar memiliki kehidupan yang panjang (long life), serta agar tidak mudah terserang penyakit degenerative dikemudian hari.

Penelitian terkait low organized games yang dilakukan oleh Purwandono (2017) tentang "Pengembangan Fundamental Movement Skill Melalui the Low Organized Games Based Program". Penelitian ini bertujuan untuk memperoleh kesimpulan tentang penggunaan The Low-Organized Games Based Program (LOGP) bagi perkembangan Fundamental Movement Skill (FMS) bagi siswa Sekolah Dasar di kelas rendah usia 7-9 tahun. Hasil penelitian ini meningkat $21 \%$ dari hasil awal $37 \%$ menjadi $58 \%$ pada hasil akhir.

Berikutnya penelitian yang dilakukan Rosidig (2012) tentang "Pengaruh Permainan Tradisional Terhadap Peningkatan Kesegaran Jasmani Siswa Kelas V SDN Tersan Gede 2
Kecamatan Salam Kabupaten Magelang". Penelitian ini bertujuan untuk mengetahui peningkatan kesegaran jasmani melalui permainan tradisonal siswa kelas V SDN Tersan Gede 2 Kecamatan Salam Kabupaten Magelang. Hasil penelitian ini meningkat pada nilai rata-rata sebesar 1,45 dari hasil awal 13,83 menjadi 15,28 pada hasil akhir.

Berdasarkan penelitian sebelumya yang membahas tentang low organized games, peneliti tertarik untuk melakukan studi tentang penerapan low organized games terhadap derajat kebugaran jasmani siswa sekolah dasar. Studi ini berjudul "Pengaruh Low Organized Games terhadap Derajat Kebugaran Jasmani Siswa Sekolah Dasar".

\section{METODE}

Dalam studi ini peneliti menggunakan metode eksperimen. Desain penelitian yang digunakan yaitu randomized pretest-posttest control group design. Pada desain ini sebelum diberi perlakuan, kedua kelompok diberi tes awal untuk mengukur kondisi awal. Selanjutnya pada kelompok eksperimen diberi perlakuan, sedangkan kelompok kontrol tidak diberi perlakuan. Setelah perlakuan selesai diberikan, kedua kelompok diberi tes akhir.

Partisipan dalam studi ini yaitu siswasiswi kelas V di salah satu Sekolah Dasar Kota Bandung. Populasi dalam studi ini berjumlah 75 orang. Teknik sampling yang digunakan dalam studi ini adalah simple random sampling. Sampel dalam studi ini berjumlah 62 orang. Sampel di bagi menjadi dua kelompok yaitu 31 orang siswa kelompok eksperimen, dan 31 orang siswa kelompok kontrol. Pengambilan sampel ini menggunakan rumus dengan taraf kesalahan 5\%.

Teknik pengumpulan data dalam studi ini menggunakan Tes Kebugaran Jasmani Indonesia (TKJI) untuk sekolah dasar sebagai alat ukur atau instrumen. Tes Kebugaran Jasmani Indonesia yang digunakan yaitu untuk anak usia 10-12 Tahun, dengan 5 butir tes yaitu: Lari cepat $40 \mathrm{M}$, Angkat tubuh, Baring duduk, Loncat tegak, dan Lari $600 \mathrm{M}$.

Analisis data dalam studi ini 
menggunakan bantuan program Statistical Product and Service Solution (SPSS) versi 22.00. Adapun langkah-langkah untuk mengolah dan menganalisis data dengan uji normalitas, uji homogenitas, uji-t (perbedaan dua rata-rata), dan uji normalisasi gain.

\section{HASIL DAN PEMBAHASAN}

Berdasarkan hasil studi dari mulai nilai pretest dan nilai posttest kelompok eksperimen dan kelompok control, jika digambarkan dalam bentuk histogram antara lain sebagai berikut:

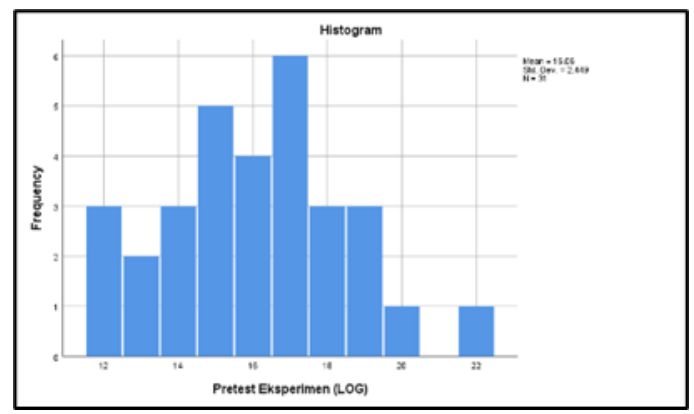

Gambar 1. Pretest Kelompok Eksperimen

Data hasil pretest pada Gambar 1, kelompok eksperimen yang mengikuti pretest sebanyak 31 orang siswa dengan jumlah nilai 498, rata-rata 16,06 dan simpangan baku 2,45. Dan data hasil posttest kelompok eksperimen pada Gambar 2, yang mengikuti posttest sebanyak 31 orang siswa dengan jumlah nilai 545, rata-rata 17,58 dan simpangan baku 2,28.

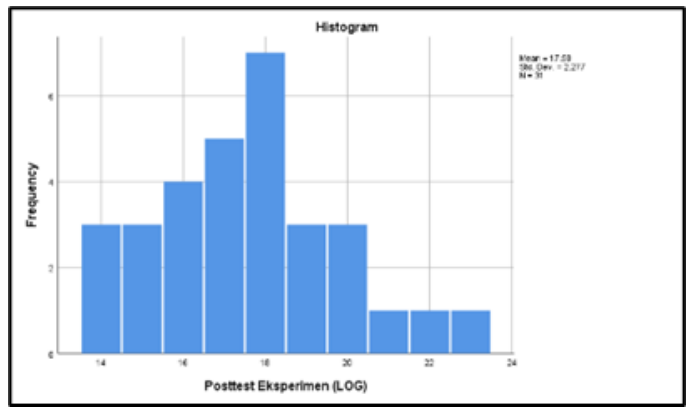

Gambar 2. Posttest Kelompok Eksperimen

Hasil uji normalitas data pretest dan posttest Kolmogorov-Smirnov pada kelompok eksperimen Sig. hasil normalitas pretest kelompok eksperimen yaitu sebesar 0.200 dan hasil posttest kelompok eksperimen yaitu 0.147. Pada uji homogenitas menunjukkan nilai Varian
Sig. sebesar 0.669 yang berarti bahwa Sig. $\geq$ 0,05 artinya $\mathrm{H}_{0}$ diterima dan $\mathrm{H}_{1}$ ditolak. Pada perbedaan dua rata-rata (uji-t) menunujukkan nilai Sig. (2-tailed) yang dihasilkan sebesar 0.014. Nilai tersebut lebih kecil dari taraf signifikansi $5 \% \quad(0,05)$ sehingga dapat dinyatakan bahwa $\mathrm{H}_{0}$ ditolak dan $\mathrm{H}_{1}$ diterima.

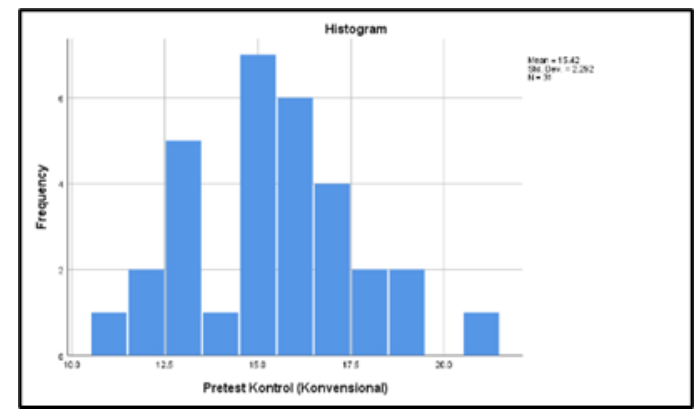

Gambar 3 Pretest Kelompok Kontrol

Data hasil pretest kelompok control pada Gambar 3 yang mengikuti pretest sebanyak 31 orang siswa dengan jumlah nilai 478 rata-rata 15,42 dan simpangan baku 2,29. Dan data hasil posttest kelompok kontrol pada gambar 4 yang mengikuti posttest sebanyak 31 orang siswa dengan jumlah nilai 518 rata-rata 16,71 dan simpangan baku 2,12.

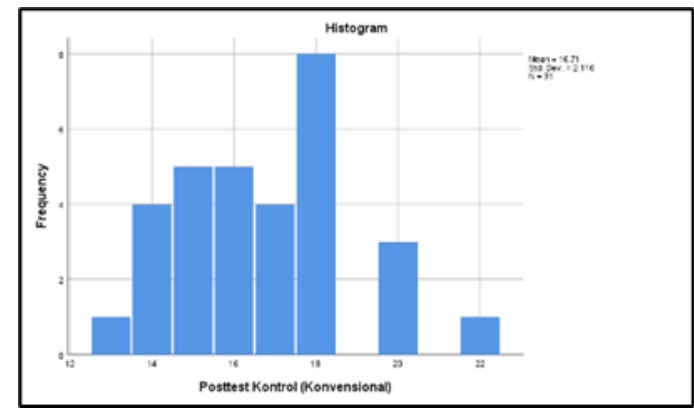

Gambar 4 Posttest Kelompok Kontrol

Hasil uji normalitas data pretest dan posttest Kolmogorov-Smirnov pada kelompok kontrol Sig. hasil normalitas pretest kelompok kontrol yaitu sebesar 0.144 dan hasil posttest kelompok kontrol yaitu 0.113. Pada uji homogenitas menunjukkan nilai Varian Sig. sebesar 0.836 yang berarti bahwa Sig. $\geq 0,05$ artinya $\mathrm{H}_{0}$ diterima dan $\mathrm{H}_{1}$ ditolak. Pada perbedaan dua rata-rata (uji-t) menunjukkan nilai Sig. (2-tailed) yang dihasilkan sebesar 0.025 . Nilai tersebut lebih kecil dari taraf signifikansi $5 \% \quad(0,05) \quad$ sehingga dapat 
dinyatakan bahwa $\mathrm{H}_{0}$ ditolak dan $\mathrm{H}_{1}$ diterima.

Data hasil perhitungan nilai gain pada kelompok eksperimen yaitu 5,55 dan rata-rata nilai gain di kelompok eksperimen 0,18. Dan data hasil perhitungan nilai gain pada kelompok kontrol yaitu 4,29 dan rata-rata nilai gain di kelompok kontrol 0,14.

Hasil uji normalitas diperoleh nilai $p$ value (Sig) dari kelompok eksperimen adalah 0.116, sedangkan uji normalitas kelompok kontrol adalah 0.182. Pada uji homogenitas menunjukkan nilai Varian Sig. sebesar 0.421 yang berarti bahwa Sig. $\geq 0,05$ artinya $\mathrm{H}_{0}$ diterima dan $\mathrm{H}_{1}$ ditolak. Pada uji perbedaan dua rata-rata (uji-t) menunjukkan nilai Sig. (2tailed) yang dihasilkan sebesar 0,029 untuk kelompok ekperimen dan kelompok kontrol. Dengan begitu nilai tersebut lebih kecil dari taraf signifikansi $5 \%(0,05)$ sehingga dapat dinyatakan bahwa $\mathrm{H}_{0}$ ditolak.

\section{PEMBAHASAN}

Pada pembahasan (uji hipotesis 1) ini peneliti melihat kondisi awal kebugaran jasmani kelompok eksperimen kemampuannya masih rendah. Hal ini dapat dilihat dengan perolehan nilai rata-rata pretest kelompok eksperimen sebesar 16,06 . Untuk meningkatkan derajat kebugaran jasmani kelompok eksperimen maka diberikannya perlakuan berupa pembelajaran low organized games. Setelah selesai diberikan perlakuan selama dua belas kali pertemuan, langkah selanjutnya melihat hasil akhir yang telah dilakukannya selama ini yaitu melakukan posttest di kelompok eksperimen. Dari hasil posttest yang diperoleh pada kelompok eksperimen adalah sebesar 17,58. Setelah dilakukan uji statistik, diketahui bahwa nilai normalitas pretest 0.200 dan nilai normalitas posttest 0.147 maka kelompok eksperimen berdistribusi normal, sebelum melanjutkan ke uji perbedaan rata-rata harus melakukan uji homogenitas terlebih dahulu, dan hasil uji homogenitas kelompok eksperimen tersebut sebesar 0.669, dikarenakan hasil uji homogenitas lebih dari 0.05 maka $\mathrm{H}_{0}$ ditolak dan hasilnya homogen. Kemudian dilanjutkan ke uji-t, hasil dari uji-t diperoleh $P$-value (Sig.2tailed) sebesar 0.014. Hal ini menunjukkan bahwa $P$-value $<^{\alpha}$ atau kurang dari 0.05 , sehingga $\mathrm{H}_{0}$ ditolak dan $\mathrm{H}_{1}$ diterima. Sehingga dapat diartikan bahwa pembelajaran low organized games berpengaruh terhadap derajat kebugaran jasmani siswa secara signifikan. Senada dengan hasil penelitian yang dilakukan oleh Yunarta (2017) menunjukkan pengaruh permainan tradisional terhadap kebugaran jasmani pada siswa kelas X (sepuluh).

Pembelajaran pendidikan jasmani yang berorientasi pada low organized games berbeda dari metode pengajaran konvensional karena pembelajaran ini berbasis aktivitas permainan yang dimana membuat siswa merasa senang, antusias dan berpartisipasi aktif dalam aktivitas pembelajaran. Berbagai pembekalan seperti skill, kebugaran jasmani, sikap, pengetahuan, dan perilaku sehari-hari harus selalu berorientasi pada kesenangan dan keyakinan individu dalam rangka pembentukan gaya hidup aktif yang sehat di masa yang akan datang (Mahendra, 2012).

Pada pembahasan (uji hipotesis 2) ini peneliti melihat kondisi awal kebugaran jasmani kelompok kontrol kemampuannya masih rendah. Hal ini dapat dilihat dengan perolehan nilai rata-rata pretest kelompok kontrol yaitu sebesar 15,42. Untuk meningkatkan kebugaran jasmani dikelas kontrol maka diberikannya perlakuan berupa pembelajaran kelompok kontrol. Setelah selesai diberikan perlakuan selama dua belas kali pertemuan, langkah selanjutnya melihat hasil akhir yang telah dilakukannya selama ini yaitu melakukan posttest di kelompok kontrol. Dari hasil posttest yang diperoleh pada kelompok kontrol adalah sebesar 16,71. Setelah dilakukan uji statistik, diketahui bahwa nilai normalitas pretest 0.144 dan nilai normalitas posttest 0.113 maka kelompok kontrol berdistribusi normal, sebelum melanjutkan ke uji perbedaan rata-rata harus uji homogenitas terlebih dahulu, dan hasil uji homogenitas kelompok kontrol tersebut sebesar 0.836, dikarena hasil uji homogenitas lebih dari 0.05 maka $\mathrm{H}_{0}$ diterima dan hasilnya homogen. Kemudian dilanjutkan ke uji-t, hasil dari uji-t diperoleh P-value (Sig.2-tailed) sebesar 0.025 . Hal ini menunjukkan bahwa $P$ value $<{ }^{\alpha}$ atau kurang dari 0.05 , sehingga $\mathrm{H}_{0}$ ditolak dan $\mathrm{H}_{1}$ diterima. Sehingga dapat 
diartikan bahwa pembelajaran kelompok kontrol berpengaruh terhadap derajat kebugaran jasmani siswa.

Pembelajaran pendidikan jasmani konvensional berbeda dari metode pembelajaran low organized games karena pembelajaran ini terlalu monoton yang dimana membuat siswa merasa cepat bosan, kurang antusias dan tifak berpartisipasi aktif dalam aktivitas pembelajaran. Upaya meningkatkan kebugaran jasmani siswa dapat dilakukan melalui pendidikan jasmani yang tepat, ada dua solusi sebagai upaya guru untuk meningkatkan kebugaran jasmani siswa. Pertama yaitu dengan modifikasi waktu jam pelajaran pendidikan jasmani. Waktu yang tersedia $3 \times 45$ menit/ minggu, dimodifikasi menjadi tiga kali pertemuan dalam seminggu. Dan solusi yang kedua yaitu dengan peningkatan strategi guru penjas dalam merancang pembelajaran menggunakan paradigma baru penjas (fun, busy, utuh, modifikasi) (Darmawan, 2017).

Dalam pembahasan (uji hipotesis 3) ini, menunjukan perbedaan dari kelompok eksperimen dan kelompok kontrol. Nilai rata-rata yang dihasilkan dari pretest kelompok eksperimen yaitu sebesar 16.06. Sementara itu nilai ratarata yang dihasilkan pretest kelompok kontrol yaitu sebesar 15.42. Hal ini menunjukan bahwa kemampuan awal kebugaran jasmani siswa masih sama-sama rendah. Sedangkan selanjutnya melihat hasil nilai rata-rata posttest kelompok eksperimen yaitu sebesar 17.58. Sementara itu nilai rata-rata posttest kelompok kontrol yaitu sebesar 16.71. Setelah melakukan perhitungan gain bahwa hasil dari uji gain ternormalisasi $(g)$ untuk peningkatan kelompok eksperimen rata-rata mengalami peningkatan sebesar 0.18. Selanjutnya peningkatan yang dihasilkan kelompok kontrol sebesar 0.14. Sehingga, dari kedua kelompok tersebut memiliki selisih sebesar 0.04. Sehingga dapat disimpulkan bahwa pembelajaran low organized games lebih berpengaruh terhadap derajat kebugaran jasmani daripada pembelajaran kelompok kontrol. Meingkatkan aktivitas fisik di sekolah, dapat mendorong partisipasi anak dalam bermain, dan bertransportasi (Andersen, 2011). Peningkatan gaya hidup aktif tidak hanya untuk kesehatan fisik, juga untuk mental. Orang dengan perilaku sedentary behavior lebih tinggi, memiliki kecenderungan kesehatan mental yang buruk (Biddle, 2011).

\section{KESIMPULAN}

Hasil penelitian dapat disimpulkan bahwa terdapat pengaruh yang signifikan dari penerapan pembelajaran low organized games terhadap derajat kebugaran jasmani siswa pada kedua kelompok, namun kelompok eksperimen lebih tinggi peningkatannya dibandingkan kelompok kontrol.

Perubahan dan peningkatan tersebut tidak bisa didapat dengan secara instan melainkan disebabkan adanya perlakuan dalam pembelajaran low organized games dan pembelajaran kelompok kontrol. Pada pembelajaran low organized games siswa mengikuti program yang diberikan dalam setiap pertemuannya menggunakan pembelajaran yang berbeda, sedangkan pada pembelajaran kelompok kontrol yaitu menggunakan pembelajaran langsung seperti biasanya yang dipelajari di sekolah selama dua belas kali pertemuan tersebut. Pada akhirnya kedua kelompok mengalami perubahan dan peningkatan yang cukup signifikan.

\section{DAFTAR PUSTAKA}

Andersen, L. B. (2011). Physical activity, fitness and health in children. Scandinavian journal of medicine \& science in sports, 21(2), 155.

Biddle, S. J., \& Asare, M. (2011). Physical activity and mental health in children and adolescents: a review of reviews. British journal of sports medicine, 45(11), 886895.

Darmawan, I. (2017). Upaya Meningkatkan Kebugaran Jasmani Siswa Melalui Penjas. Jurnal Inspirasi Pendidikan, 7(2), 143-154.

Giriwijoyo, S., \& Zafar S. (2010). Ilmu Faal Olahraga. Bandung: FPOK UPI.

Giriwijoyo, S., \& Zafar S. (2012). Ilmu Kesehatan Olahraga. Bandung: PT Remaja Rosdakarya.

Juliantine, T., Subroto, T., \& Yudiana, Y. (2015). Model-model Pembelajaran Dalam Pendidikan Jasmani. Bandung: 


\section{FPOK UPI.}

Mahendra, A. (2007). Permainan Anak dan Aktivitas Ritmik. (Modul). Jakarta: Pusat Penerbitan UT.

Mahendra, A. (2012). Model Pembelajaran Pendidikan Jasmani. Bandung : Modul Pembelajaran.

Nuryadi, N., Negara, J. D. K., Juliantine, T., Slamet, S., \& Gumilar, A. (2018). Hubungan Kebugaran Jasmani dengan Kemampuan Konsentrasi dan Respon Kortisol. Jurnal Pendidikan Jasmani dan Olahraga, 3(2), 122-128.

Purwandono, A. (2017). Pengembangan Fundamental Movement Skills Melalui The Low Organized Games Based Program. (Tesis). Sekolah Pascasarjana Universitas Pendidikan Indonesia, Bandung.

White, G., Casebolt, K., \& Hull, S. (2004). Low - Organized Games: An Approach to Inclusion. Strategies: A Journal for Physical and Sport Educators, Vol 18, 2004 - Issue 2. Doi: https:// doi.org/10.1080/08924562.2004.1059112 4

Yunarta, A. (2017). Pengaruh Permainan Tradisional Terhadap Kebugaran Jasmani Pada Siswa Kelas X Madrasah Aliyah Negeri Jombang Tahun Pelajaran 2017/2018. Bravo's: Jurnal Program Studi Pendidikan Jasmani dan Kesehatan, Vol 5, No 4. Doi: https://doi.org/10.32682/ bravos.v5i4.638 